\title{
ETHNOBOTANICAL STUDIES ON THE FLORA OF YAVATMAL DISTRICT - SOME INTERESTING REPORTS OF HERBAL MEDICINES
}

\author{
Ravindra S. Matte \\ Dept. of Botany, Lokmanya Tilak Mahavidyalya, Wani, M.S., India. \\ Corresponding author Email : ravindramattewani@gmail.com
}

\begin{abstract}
:
The present paper deals with some herbal medicines employed the tribals of Yavatmal District. 30 interesting medicinal plants have been reported in the present paper along with their local names, brief description and way the plant or the plant parts are employed. Either these plants have not been mentioned by the earlier worker or the uses mentioned here are quite different from the previous reports, and the present study should form a significant contribution towards the understanding of our herbal remedies for various ailments.
\end{abstract}

Keywords:

Ethnobotany, medicinal plant, tribes. Medicinmen, herbal remedies

\section{Introduction:}

All system of traditional Indian medicine had their roots, in one way or the other, in folk medicines and household remedies. Whereas some of those earliest remedies and prescription become widespread and were subject to certain refinements, revision and improvements, through practices by trained medicinmen and thus got incorporated in organized system of medicines, much larger number of folk-medicines remained endemic to certain regions or people in the country. Due to lack of communication, of intermingling and of breeding of ideas, as also due to the varying ways of life, many of these earlier remedies survived only by word of mouth from generation to generation. These not only exist but are being largely practiced in many parts of our country, particularly in remote rural and tribal societies. The lack or absence of accumulation has, in many instances, helped in the preservation of this knowledge in almost original form. Yavatmal district offers an immense scope for such ethnobotanical studies since it is mostly inhabited by numerous aboriginal tribes where there is a rich folklore. The surrounding plants for these people 
form an integral part of their culture and the information about plants gets passed on from generation to generation only through oral folklore and many times kept secret. These people like to stay in remote places in jungles and cannot be approached easily by other people. The district of Yavatmal lies between $19026^{\prime \prime} \mathrm{N}$. and 42" $\mathrm{N}$ latitude and 77o 18" E and 790 E"longitudes. It has an area of 13,517 square kilometers and a population of 2,775, 457 according to the 2011 census figures, distributed among 8 town and 1,629 villages. Admistratively, the district is bounded on its north-west by Washim, district, Mangrulpir and Murtizapur Tahsil of Akola district, on the north, by the Amravati district, on the north east by Warora, Chandrapur, and Rajura Tahsil of Chandrapur district. On the south, it is bounded by the Kalamnuri Tahsil of Parbhni district, Hadgaon and Kinwat Tahsils of Nanded district and by the northern Tahsils of Adilabad district of Andhra Pradesh state. Voucher specimens of the species reported in this paper were collected in the field and the information about plants were recorded with the native people. Specially the people who are familiar with the herbal medicines were practiced in preserving the specimens for the herbarium (Jain and Rao, 1977).

\section{Material and Method:}

A survey was carried out during 20010 to 2012 to collect information on the medicinal uses of plants found in the tribes inhabited villages of Zhari, Bori, Patan, Ghonsa, Zamkola, Arjuni, Sakhara, Botony, Shibla, Junoni Marki. and Raypur. The information was documented involving field study by contacting and interviewing vaids, ojhas for plants used to cure various types of fever. Ethnobotanical data were collected according to the methodology suggested by Jain. The ethnobotanical data (local name, mode of preparation, medicinal uses) were collected through questionnaire, interviews and discussions among the tribal practitioners in their local language. The information recorded in field was further screened in laboratory as per work pertaining to Indian ethnobotany and plants recorded by Chopra et.al. (1982), Nadkarani (1982), Jain 
(1981, 1991) , Jain (1996), to distinguish the information already known, reported and published by taxonomists and ethno-botanist and little known and unpublished work. ENUMERATION OF PLANTS: In the following enumeration, only some important medicinal plants are mentioned. The species are arranged according to alphabetical order. Local names and followed by brief description of the species, distribution and the native uses along with methods of application. Achyranthes aspera. Linn. (L.N. Atenpera) An erect herb. Leaves opposite decussate, simple, cuneate. Flower in terminal or axillary spikes, pink. Fruit a utricle, seed one. Commonly found in the cultivated field and open ground. The decoction of the root with water is a good diuretic, which acts on the kidney and tends to increase their secretion. Andrographis paniculata Burm. (L.N.Bhuilimba) Andrographis paniculata grows erect to a height of 30-110 cm in moist shady places. Stem slender stem is dark green.

Leaves the lance shaped. Flowers the small flowers are borne in spreading racemes. Common in the forest region near the water sources. Decoction or strong infusion of the root-stalked and leaves are a household febrifuge, bitter tonic alterative anthelmintic and antiperiodic, useful in fever and malaria. Anona squamosa. Linn. (L.N. Sitabar) A small tree with dark brown bark.

Leaves long, oblong or oblong-lanceolate. Flowers solitary and leaf opposed or 2-4 on short extra axillary branches. Common in open places and in cultivated field and hilly region. The root is a violent purgative. The bark is a powerful astringent and as a tonic is much used in medicine. Leaves are applied for extractions of worm. Argyreia nervosa Linn. (L.N. Sagara) Very large climber. Leaves 2 to 6 inch long ovate- cordate to linear lanceolate, entire pubescent or silky beneath. Flowers white purple or rose capitate cymes. Occasionally found in the forest areas or planted by people near the house Root is an alternative and tonic, powdered root is given in milk in synovitis and syphilis. Leaves are aniphlogistic and used in skin diseases. Barleria prionitis Linn. Shrub. Leaves opposite, entire, lanceolate-ovate, between the branch and the leaf there is a spine with four sharp rays from the same centre. Flowers sessile, axillary 
orange coloured Common in open ground places throughout the district. Bark dried in sunlight and making a powder and used for cough. Whole root boil and applied on the glandular swelling. Bauhinia racemosa, Lam. (L.N. Arre) A small tree, bark-brown, rough. Leaves broader than long, coriaceous, grey beneath, cordate. Flowers in terminal or leaf opposed racemes. Common in jungle clearings areas and hilly region. The bark is astringent, tonic and alterative; it yields a brown coloured gum. The bark rubbed in to an emulsion with rice water and administered with the addition of ginger in scrofulous enlargement of the glands of the neck. Bombax ceiba Linn. (L.N. Buruj) A tall deciduous tree. Leaves large, spreading glabrous, digitate, leaflets lanceolate. Flowers red, numerous, appearing when the tree is bare of leaves. Common in forest areas and along the road sides. Fresh root collect early in the morning making a powder and used in leucorrhea. Bark paste mix with edible oil and used in wound. Bryonopsis laciniosa Linn. (L, N. Shivlinge) A climber. Leaves long, cordate at the base rough above the margin sinuate. Flowers small 3-6 yellow flowered fascicles; Occasionally found in the forest areas or planted by people near the house. Fresh leaves crushed in cold water and making syrup and with courd given in piles. Extract of the leaves used in round worm. Caesalpinia bonduc Linn. (L.N Gotta) A large prickly climbing shrub. Leaves long, pinnate, rachis prickly, stipule large, opposite. Flowers long axillary or terminal racemes. Common in jungle clearings areas and hilly region. The seed and root bark are noted as antiperiodic, antispasmodic, it is used in asthma and fever. Calotropis gigantea. Linn. (L.N.Chiladam) Large shrub. Leaves opposite leaves are oblonglbobate to nearly orbicular, short pointed to blunt at the apex and have very short petioles below a nearly clasping, heart -shaped base. Flowers clusters are umbelliform cymes. Commonly found in waste land. Root bark is useful in skin diseases, asthma. The milky juice is recommended for the cold. The dried flower powder mix with honey and used on Cough Cappparis sepiaria Linn. (L.N.waghatte) A straggling large shrub with brow bark and young shoots pubscent. Leaves elliptic or obovate, acute to obtuse, stipular spines hooked. 
Flowers small white, insubsessile umbels, long. Occasional in dense forest. Fresh root bark decoction used in rheumatism. Bark decoction used in dropsy. Cassia fistula Linn. (L.N. Bammwa) A moderate sized tree, bark smooth. Leaves parapinnate, long, rachis terete, leaflets 4-8 pairs, ovate or ovate-oblong. Flowers in pendulous axillary raceme, Occasional in dense forest, Root is useful in fever, heart diseases, retained excretions, etc. Externally the leaves round into a paste are applied to ringworm. Catharanthus roseus Linn. (L.N. Jaganathii) Perennial sub shrub, woody at base $30-60 \mathrm{~cm}$ tall. Leaves oblong or oblanceolate membranous, entire, obtuse or mucronate, base obtuse or cuneate, Flowers inflorescence of axillary 1-4 flowered cymes, flowers pink or white. Common in open places. Decoction of the root used on cancer patient.

Whole plant boiled and decoction used on the regular menstruation cycle. Celosia argentea L. (L.N. Kombda) Erect annuals. Leaves linear-lanceolate or ovate-elliptic. Flowers pinkish at first after wards turning to white, in close cylindric spikes sometimes branching at the apex. Commonly found in the cultivated field and open ground. Decoction of the leaves used on fever. Root powder mix in hot water and used on kidney stone. Gymnema sylvestre Retz. (L.N.Goodmar) Large climbers, rooting at nodes, Leaves elliptic, acuminate, base acute to acuminate. Flowers small, in axillary and lateral umbel like cymes, pedicels long; Calyx-lobes long, ovate, obtuse, pubescent; yellow campanulate, valvate, corona single Occasional in dense forest, Decoction of the leaves given in diabetes patient. Decoction of the whole plant used in asthma. Fresh root paste applies on the snake bite. Holarrhena antidysenterica Heyne ex. (L.N.Dudhekurhe) A small tree with pale bark. Leaves opposite, long, elliptic-oblong, acute or acuminate membranous. Flowers white slightly scented, in terminal corymbose cymes. Occasional in dense forest, The bark of the stem and root, preferably of the young plants and seeds, are recommended as remedies in acute and chronic diarrhoea and dysentery. Jatropha curcas Linn. (L.N.Chandrajoti) A large shrub. Leaves alternate, cordate, 5-lobed or angled, petiole long. Flowers yellowish-green, monoecious, in cymose panicles, 
bract acute, . The leaves warmed and rubbed with castor oil and applied to boils and abscesses have the supportive effect. Maytenus emarginata willd. (L.N.Datti) A densely branched armed shrub. Leaves alternate distichous, simple, Flower in axillary or terminal, condensed or diffused cymes, fragrant, white. Common in jungle clearings areas and hilly region. Young petiole dried and making a powder and used in dhat. Leaves powder mix with coconut oil and making a paste and apply on wound. Momordica dioica Roxb. (L.N.Karli) A perennial climber with tuberous root, slender stem, tendril elongate. Leaves variable, membranous, and cordate at the base, puncate, entire or 3- 5 lobed, petiolate. Flowers male flowers solitary, female flowers solitary. Commonly found in the field, open ground and along the road sides Juice of the leaves mixed with coconut oil to form an ointment, and applied to the head relieves headache. Nerium indicum Mill. (L.N. Hajarfugadi) A large glabrous branchy shrub. Leaves in whorls, long. Linear-lanceolate. Flowers fragrant varying from white to dark- red in colour. Common throughout the district. Root is used externally, made in to paste with water and applied to hemorrhoids", in cancers and ulcerations. Root is used for applying or tying to the ear of the patient suffering from fevers. Semecarpus anacardium Linn. (L.N.Siddi) A large tree. Leaves alternate, simple, crowded at the tips of the branches, obovate-oblong. Flowers greenish- white, fascicled, bracts lanceolate. Occasional in dense forest, The fruit powder in water is used for gargling in throat infection. Fruit oil used for massage by rheumatic patients. The fruit powder used in the worm in children. Spilanthes acmella Muri. (L, N. Akkarekara) Annual erect tout herbs, $20-50 \mathrm{~cm}$ high. Leaves Opposite, petiolate, broadly ovate, narrowed at base. Flower In axillary and terminal panicles, involucres bracts 2 -seriate; Ray florets few, in conspicuous; Disc florets campanulate. Commonly found in waste land and marshy places. The flower heads are chewed to relieve the toothache and other mouth related troubles. Leaves are used externally in treatment of skin diseases. Tridax procumbens Lin. (L.N. Kambarmodi) A decumbent herb. Leaves simple, opposite, exstipulate and margins dentate 
showing reticulate venation. Flowers a terminal heterogamous head and receptacle of the head is convex and surrounded by green involucres. Commonly found in waste land and cultivated field. Plant extract is used as antiseptic. Paste helps the wound to heal quickly. Plant ash in coconut oil applied on wounds. Plant decoction for stomach diseases, Terminalia arjuna Roxb. (L.N.Arjunemak) A large tree with smooth pale-grey bark peeling off in large flakes. Leaves long, oblong or elliptic-oblong, glabrous, Flowers sessile, small greenish-yellow, in short axillary spikes or terminal panicles. Common in jungle clearings areas and hilly region. Decoction of the bark is given to the fever. Decoction of leaves used in roundworm. Externally leaves are used for covering ulcers and sores.

\section{Result and Discussion:}

The present investigation revealed over thousand used of more than 200 to 300 plants out of which this investigation report 24 unique plant. Usage of these plants mainly is to treat asthma, disorder associated with lactation menstrual problems, poisonous bites, skin problem, stomach ache and toothache, etc. Ethnomedicinal studies preferably promote the interaction between organized traditional medicine and folk medicine. It is observed that most of the tribals do not accept any other medicine except the ones prescribed by their medicinmen. A large section of the Indian population, living in village, remote forests and sometimes even in cities, still depend on folk medicines and household remedies, it cannot be overemphasized that information on all such knowledge should be recorded at the earliest, and scientifically tested for blending in to other traditional Indian system of medicine.

\section{Conclusion:}

abcHerbal remedies and traditional medical practitioners play an important role in health care of millions of people in developing countries. In some countries like India a large percentage of population does not have access to 
western medical care. The severe side effects of many powerful synthetic drugs and lack of causally effective drugs certainly is one of the puzzling features of modern pharmacology. This motivation is enough to increase our faith in Biomedicines and make efforts to search for new and better drugs from plants.

\section{Reference:}

Chopra RN.Chopra IC, Handa KL, Kapur LD.1982. Indigenous Drugs of India. Second edition (Reprinted) Academic Publishers, New Delhi.

Jain SK. 1963. Observation on Ethnobotany of tribals of M.P. Vanyajati 11(4): 177-187.

Jain SK. 1975. Ethnobotany of Central India Tribals. J. Indian. Bot. Soc.

Abstract. 1 (6): 63.

Jain SK (edited). 1981. Glimpse of Indian Ethnobotany. New Delhi:Oxford and I.B.H Pub.

Jain SK. 1991. Dictionary of Indian Folk Medicines and Ethnobotany. New Delhi: Deep Pub.

Jain SP. 1996. Ethno- Medico -Botany cal survey of Chaibasa singbhum district, Bihar J. Econ .Tax. Bot. Addl Series: 12: 403-407.

Nadkarani AK. 1982. Indian Materia Medica Popular Prakashan Bombay Vol I\&II (reprinted).

Pimbert, M. and J. Pretty, 1995. Parks, people and professionals: Putting participation into protected area management. UNRISD Discussion Paper 57, Geneva. 